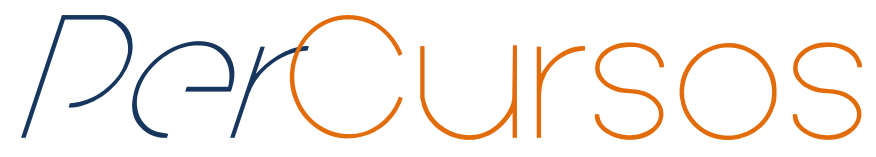

\title{
A requalificação da paisagem e os espaços multifuncionais no entorno da Usina Mourão I, Campo Mourão/PR
}

\begin{abstract}
Resumo
O reservatório da Usina Hidrelétrica Mourão I foi criado na década de 1960 e, desde então, a paisagem de seu entorno passou por um intenso processo de transformações com a requalificação de seus usos e a multifuncionalização do espaço. $O$ espaço, que antes era rural, passou a desempenhar funções diversas dentre as quais se destacam o desenvolvimento de atividades de lazer e a instalação de empreendimentos destinados ao uso recreativo da água. A pesquisa teve como objetivo analisar a requalificação da paisagem no entorno do reservatório da Usina Hidrelétrica Mourão I, enfatizando a multifuncionalidade do espaço bem como sua apropriação para os distintos tipos de usos, com especial destaque para os recreativos. A partir de atividades de mapeamento e de observações de campo, foram identificados inúmeros usos recreativos do lago e/ou vinculados a ele, os quais foram classificados em quatro categorias: 1) Chácaras urbanas com estrutura já consolidada; 2) Novos loteamentos e condomínios; 3 ) Espaços populares e privados de uso coletivo; 4) Parque Estadual Lago Azul - PELA, uma unidade de conservação de uso coletivo. Pôde-se constatar que tem aumentado o número de áreas de lazer e recreação implantadas nas margens do lago da usina e que elas vêm desenvolvendo uma paisagem seletiva, elitizada e requisitada para a instalação de empreendimentos, especialmente imobiliários de alto padrão.
\end{abstract}

Palavras-chave: Lazer. Espaço rural. Usina hidroelétrica. Valorização imobiliária.

\section{Dienifer Fernanda dos Santos}

Geógrafa e especialista em Geografia,

Meio Ambiente e Ensino pela

Universidade Estadual do Paraná -

UNESPAR.

Brasil

dieniferfsantos@outlook.com

\section{Ana Paula Colavite}

Doutora em Geografia pela Univ. Estadual de Maringá. Professora do Programa de Pós-Graduação Interdisciplinar Sociedade e Desenvolvimento da Univ. Estadual do

Paraná - UNESPAR. Brasil

apcolavite@hotmail.com

\section{Cláudia Chies}

Doutora em Geografia pela Univ. Estadual de Maringá - UEM. Professora Adjunta do colegiado de Geografia da Univ. Estadual do Paraná - UNESPAR Brasil claudiachies@hotmail.com

\section{Adriano Ferreira Guimarães}

Mestre em Bioenergia pela Universidade Estadual do Oeste do Paraná - UNIOESTE. Brasil

adrianofguimaraesguimaraes@gmail.com

\footnotetext{
Para citar este artigo:

SANTOS, Dienifer Fernanda dos; COLAVITE, Ana Paula; CHIES, Cláudia; GUIMARÃES, Adriano Ferreira . A requalificação da paisagem e os espaços multifuncionais no entorno da Usina Mourão I, Campo Mourão/PR. Revista PerCursos, Florianópolis, v. 20, n.43, p. 167 - 194, maio/ago. 2019.
} 


\title{
The requalification of landscape and multifunctional spaces in the environment of Mourão I, Campo Mourão/PR - Brazil
}

\begin{abstract}
The reservoir of the Mourão I Hydroelectric Power Plant, was created in the 1960's and since the landscape of its surroundings has undergone an intense process of transformation, with the requalification of its uses and the multifunctionalization of space. The area, which used to be a rural area, began to perform diverse functions, among which the development of leisure activities and the installation of recreational water use projects. The research aimed to analyze the landscape requalification around the reservoir of the Mourão I Hydroelectric Power Plant, emphasizing the multifunctionality of this space, as well as its appropriation for the different types of uses, especially the recreational ones. From the mapping and field observation activities, several recreational uses of the lake and / or related to the lake were identified, which were classified into four categories: 1) Urban farms with already consolidated structure; 2) New subdivisions and condominiums; 3) Popular and private spaces of collective use; 4) Parque Estadual Lago Azul - PELA, a conservation unit for collective use. It could be verified that there has been an increase in the number of leisure and recreation areas located on the banks of the lake and that these have been developing a selective, elitist and required landscape for the installation especially of high-quality real estate projects.
\end{abstract}

Keywords: Recreation. Rural space. Hydroelectric plant. Real estate valuation. 


\section{Introdução}

Este artigo aborda as relações entre a requalificação da paisagem e a multifuncionalidade do espaço, materializadas nas distintas categorias e tipologias de usos do solo, identificadas no entorno do reservatório da Usina Mourão I, localizado no interior do estado do Paraná. Compreende-se que, nessa localidade, as características da paisagem são fatores preponderantes para a diversificação dos usos e espaços e das atividades, especialmente as de lazer e recreação.

Após a implantação da usina hidrelétrica Mourão I, na década de 1960, o entorno do reservatório, que antes se situava em uma área predominantemente rural, passou a atrair o interesse para novos usos, notadamente a criação de chácaras de lazer. Passou, portanto, por um processo de requalificação de sua paisagem. Da mesma forma, a água represada para produção de energia adquiriu uma nova função, a de servir à recreação da população local. Com isso, tais alterações, processadas a partir da construção da hidrelétrica, levaram esse espaço a se tornar multifuncional e o que melhor o caracteriza, na atualidade, são suas funções de lazer.

Para Batty et al. (2004), o multifuncionalismo do espaço é um conceito relativo pois depende da escala espacial e temporal utilizadas, sendo aplicado para analisar a mistura e a concentração de usos do solo. Ao mesmo tempo, o cotidiano vivenciado nas cidades contemporâneas tem levado a população a buscar, em seus momentos de lazer, o convívio em espaços naturais, atribuindo a eles uma nova função decorrente de suas qualidades paisagísticas.

Ferreira, Lopes e Araújo (2005) destacam que a paisagem é essencial para o desenvolvimento da atividade turística, tornando-se um dos principais atrativos, especialmente quando associado aos espaços naturais, e a água desponta como um dos elementos de grande importância nessa dinâmica. Desta forma, para Lopes, Carvalho e Magalhães Jr. (2011, p. 179), “independentemente dos impactos da urbanização nos seres humanos e de sua busca pelo espaço natural, as águas sempre foram elementos de atração para fins de lazer e pelo seu significado simbólico e cultural”. 
Complementando a ideia, Dias e Granado (2014, p. 679) apontam que "os ambientes aquáticos parecem compor as opções de lazer e recreação preferidas em todo o mundo" ao passo que Ferreira, Lopes e Araújo (2005, p. 139) indicam que "Um dos principais atrativos para turistas que buscam diversão e descanso são reservas de águas, sejam elas naturais ou artificiais. Como exemplo, podem-se citar as praias, lagoas, rios, barragens, balneários, cachoeiras, entre outros".

A construção de hidrelétricas promove profundas transformações na paisagem (COELHO; PEREIRA, 2011) alterando o padrão de uso e requalificando as atividades no espaço do seu entorno, tornando-as mais diversas e diferenciadas. Além de a paisagem adquirir novos significados, o espaço se torna mais atrativo ao setor econômico, notadamente o imobiliário, que vê nele a possibilidade de parcelamento do solo, para a venda de lotes e a criação de áreas de lazer, as quais, por sua proximidade com o curso d’água, agregam, junto com a vegetação, valor ao lugar.

Diante dessa perspectiva, neste artigo teve-se o objetivo de analisar a requalificação da paisagem no entorno do reservatório da Usina Hidrelétrica Mourão I, enfatizando a multifuncionalidade desse espaço bem como sua apropriação para os distintos tipos de usos, com especial destaque para os recreativos.

\section{Percursos metodológicos}

O desenvolvimento da pesquisa baseou-se em atividades laboratoriais e de pesquisa de campo a partir das quais foram elaborados os produtos apresentados no artigo e as análises propostas. Na etapa laboratorial, utilizou-se das seguintes ferramentas e procedimentos:

1) no SPRING (Sistema de Processamento de Informações Georreferenciadas): a) construiu-se o banco de dados, foram vetorizados os rios e os limites da bacia a partir das cartas topográficas Campo Mourão, Luiziana e Mamborê (articulações MI-2803/1, MI2803/3, MI-2802/4); b) o Mapa de Uso da Terra foi construído a partir do Processamento Digital de imagem do satélite RapidEye de 2014 (bandas 1-r, 2g, 3-b), melhoradas com funções de contraste e classificadas pelo processo semiautomático. Com base no mapeamento, calculou-se a área total de cada tipo de uso. 
2) no QGis foi elaborado o mapa de localização, com a delimitação política obtida em arquivo shapefile no IBGE (2015); a carta imagem foi elaborada a partir de dados da plataforma Bing Maps, acessada via Open Layers plugin.

3) no Google Earth Pro acessaram-se imagens com variações temporais diversas, disponíveis para cada ponto analisado, a partir da ferramenta imagens históricas. Privilegiaram-se as imagens que melhor representavam o elemento em estudo. Também se obtiveram imagens no Google Earth Web.

4) no Corel Draw realizou-se a edição final do layout dos mapas e das demais imagens apresentadas no artigo.

A etapa de campo compreendeu três campanhas nas quais se observou a paisagem, registrou-se coordenadas com o receptor de sinal GPS, obtiveram-se fotografias e realizaram-se conversas informais com proprietários e transeuntes locais.

\section{A construção de usinas hidrelétricas e o uso recreativo dos lagos artificiais}

O uso da água para finalidades recreativas é registrado desde a Antiguidade com os povos egípcios, há 3.000 anos a.C., quando a água era de uso exclusivo da casta nobre. Porém, foi durante o Império Romano que o uso da água em atividades recreacionais se disseminou entre a população, proporcionando o lazer à sociedade. Muitos séculos depois, na Europa Medieval, a popularização do uso da água para diversão, associada à falta de saneamento básico, desencadeou o surgimento de doenças que levaram ao fim desse uso comum nas cidades dessa época (LOPES; JESUS, 2017; VON SPERLING, 2003).

Historicamente, os recursos hídricos são fontes essenciais para o desenvolvimento socioeconômico nas mais diversas culturas do mundo. O uso recreativo de contato primário com os recursos hídricos, ou seja, a relação direta e prolongada com a água (natação, mergulho, esqui aquático) sempre esteve presente na cultura humana, sendo considerado um dos usos mais nobres, decorrentes de sua importância social e cultural em sociedades que associam esse contato ao simbolismo religioso (LOPES; JESUS, 2017; MINISTÉRIO DO MEIO AMBIENTE, 2005; VON SPERLING, 2003). Em outras culturas, a 
água é vista primeiramente como uma fonte natural, essencial para a subsistência humana, e para as mais diversas formas de uso.

Os usos múltiplos da água podem ser classificados em consuntivos e não consuntivos. O uso consuntivo remete à retirada de certa quantidade de água e, após o seu uso, parte dela é devolvida ao seu local de origem tendo, como exemplo, as atividades de abastecimento de energia, irrigação, dentre outros usos que alteram a qualidade e quantidade da água. O uso não consuntivo consiste na retirada de parte da água a qual, depois de utilizada, é devolvida novamente com a mesma quantidade e qualidade ou, ainda, é utilizada como fonte de abastecimento de atividades diversas, como a pesca e a navegação (CARVALHO; SILVA, 2006).

A construção de barragens, com o represamento de rios, para a implantação de usinas hidrelétricas, altera a dinâmica natural dos recursos hídricos propiciando novas formas de uso da água e influi, também e diretamente, na produção do espaço de seu entorno. Se, por um lado, a implantação de usinas hidrelétricas, ou pequenas centrais hidrelétricas, causam impactos negativos no meio físico-biológico, por outro possibilita a exploração de usos múltiplos da água e das potencialidades criadas pelo reservatório, como elemento indispensável à vida ou como insumo nas atividades produtivas, como a navegação, a irrigação, as práticas de turismo, o lazer e a recreação (NASCIMENTO, 2011; OLIVEIRA, 2004).

Para Queiroz e Motta-Veiga (2012), as implantações de empreendimentos hidrelétricos produzem significativos impactos de ordens e naturezas distintas: ambientais, com mudança do bioma e interferência na cadeia alimentar e nos processos de produção nativa; sociais e na saúde, especialmente com a mobilidade forçada da população ribeirinha, promovendo ruptura social e alterações no seu modo de vida. Os autores salientam ainda que os impactos ambientais são ponderados no Estudo de Impacto Ambiental, atestando ou não a viabilidade do empreendimento; já os impactos na sociedade não constam do planejamento "redundando em ações mitigadoras e compensatórias tardias e insatisfatórias" (QUEIROZ; MOTTA-VEIGA, 2012, p. 1388).

Piacenti et al. (2003) salientam que a implantação de usinas e centrais hidrelétricas influi na dinâmica do desenvolvimento regional pois promove a reestruturação das 
atividades produtivas, incrementando atividades até então não exploradas. O uso alternativo dos reservatórios para o turismo, o lazer, a pesca, o comércio de energia, o recebimento de royalties, dentre outros, são exemplos de atividades que reorientam a economia local.

Em pesquisa de mestrado, realizada por Pereira (2006), os resultados indicaram a relevância do uso recreativo do Lago Paranoá (Distrito Federal), especialmente o uso náutico, para a valoração econômica do meio ambiente, com gastos econômicos consideráveis por parte dos usuários. Entretanto, destaca-se que o uso recreativo está restrito a uma elite e, por encontrar-se em plena expansão, o poder público deve estabelecer diretrizes de gestão deste espaço, baseado no que rege a legislação brasileira.

Sobre o uso recreativo do Lago de Itaipu, Pertille (2007) expôs que a exploração da paisagem que foi transformada com a criação do reservatório começou a ser organizada a partir da década de 1990 e que, embora o reservatório contemple a área de 16 municípios, apenas 8 utilizam a água para finalidades recreativas, a partir dos terminais turísticos. Atualmente, o uso turístico e de lazer nessa região está estruturado em projetos regionais e locais que visam atender aos Objetivos de Desenvolvimento Sustentável (ODS) e apresentam alta diversificação de atividades e ações, as quais englobam projetos de educação ambiental, de incentivo à prática esportiva e até ações concretas de planejamento e elaboração de convênios e consórcios intermunicipais para instalação de infraestrutura (CONSELHO DE DESENVOLVIMENTO DOS MUNICÍPIOS LINDEIROS AO LAGO DE ITAIPÚ, 2018).

De acordo com Rocha et al. (2013), a implantação da UHE Balbina, na Amazônia, alterou a paisagem do local, facilitou a mobilidade e o acesso à infraestrutura, notadamente de vias de transporte e de rede elétrica, além de criar novas formas de ocupação da terra, dentre elas o uso recreativo, tanto para os moradores locais quanto para os visitantes que são atraídos por essa finalidade.

Observa-se, portanto, que, após a implantação de usinas hidrelétricas, a paisagem passa por transformações e adquire novas funções. O reservatório de águas se torna um 
vetor para a multifuncionalização do espaço e um atrativo para a população que procura nele o local para o desenvolvimento de atividades de lazer e recreação.

O lazer foi transformado em necessidade para a sociedade contemporânea não sendo apenas uma busca para a compensação do tempo livre do trabalhador, mas, também, uma necessidade criada pelo modo de produção capitalista como uma forma de se apropriar do seu tempo livre (CRUZ, 2003). Independente dos impactos da urbanização sobre a população e do cotidiano atribulado, na busca por espaços naturais os recursos hídricos sempre foram um elemento atrativo para o lazer e a recreação, pelo seu significado simbólico, cultural e até mesmo relaxante (LOPES; CARVALHO; MAGALHÃES Jr., 2011).

Os problemas urbanos, como a concentração populacional, a verticalização da cidade, a poluição, a formação de ilhas de calor, o trânsito caótico, a ausência de espaços verdes, a segregação e a desigualdade socioespaciais, dentre outros, enfrentados na atualidade, causam sérios riscos à saúde física e mental da população. Além disso, o crescimento populacional junto à expansão urbana, aliado à falta de políticas públicas eficazes, vem reduzindo áreas verdes que podem desenvolver funções ecológicas, sociais e de lazer, tornando as cidades cada vez menos acolhedoras para a população urbana (LONDE; MENDES, 2014). Sob essas condições, rios e represas atraem visitantes, tanto da localidade quanto da região em que estão inseridos, sendo os pequenos municípios beneficiados por seus ambientes aquáticos como espaços destinados à recreação (DIAS; GRANADO, 2014).

O lazer contemplativo é uma das principais modalidades de utilização da água. Tem como função desenvolver a harmonia paisagística exercida pelos recursos hídricos, ou seja, o entorno de rios, lagos e represas, e estimulam a realização de diversas atividades recreativas como pesca, navegação, esqui aquático, natação, mergulho, dentre outros tipos de contatos primários com a água (LOPES; JESUS, 2017).

$\mathrm{Na}$ interface das relações entre a construção de usinas hidrelétricas e seus efeitos nas transformações socioespaciais de seu entorno, observa-se a viabilização de zonas residenciais às margens do lago. Muitas vezes, essas propriedades são caracterizadas como uma segunda residência para uma parcela da população com maior poder 
aquisitivo que tem nesse espaço o local de descanso e contemplação da beleza cênica. Diante do exposto, na sequência é apresentada uma breve discussão sobre o processo de requalificação da paisagem após a construção da Usina Mourão I.

\section{A construção do reservatório da Usina Mourão I e a requalificação da} paisagem no seu entorno

O reservatório da Usina Mourão I, foi instalado no curso médio do rio Mourão que possui área de drenagem de $612 \mathrm{~km}^{2}$, abrangendo parcela dos municípios de Campo Mourão, Luiziana e Mamborê (Figura 1), localizados no interior do estado do Paraná. O reservatório é formado pela confluência do Rio Mourão com o Rio Sem Passo. A bacia hidrográfica compreende uma vasta rede de drenagem e o canal original é composto por duas grandes quedas, onde foram implantadas as centrais hidrelétricas Mourão I e Salto Natal (situada a jusante da primeira).

Figura 1 - Mapa de localização da Área de Influência da Usina Mourão I

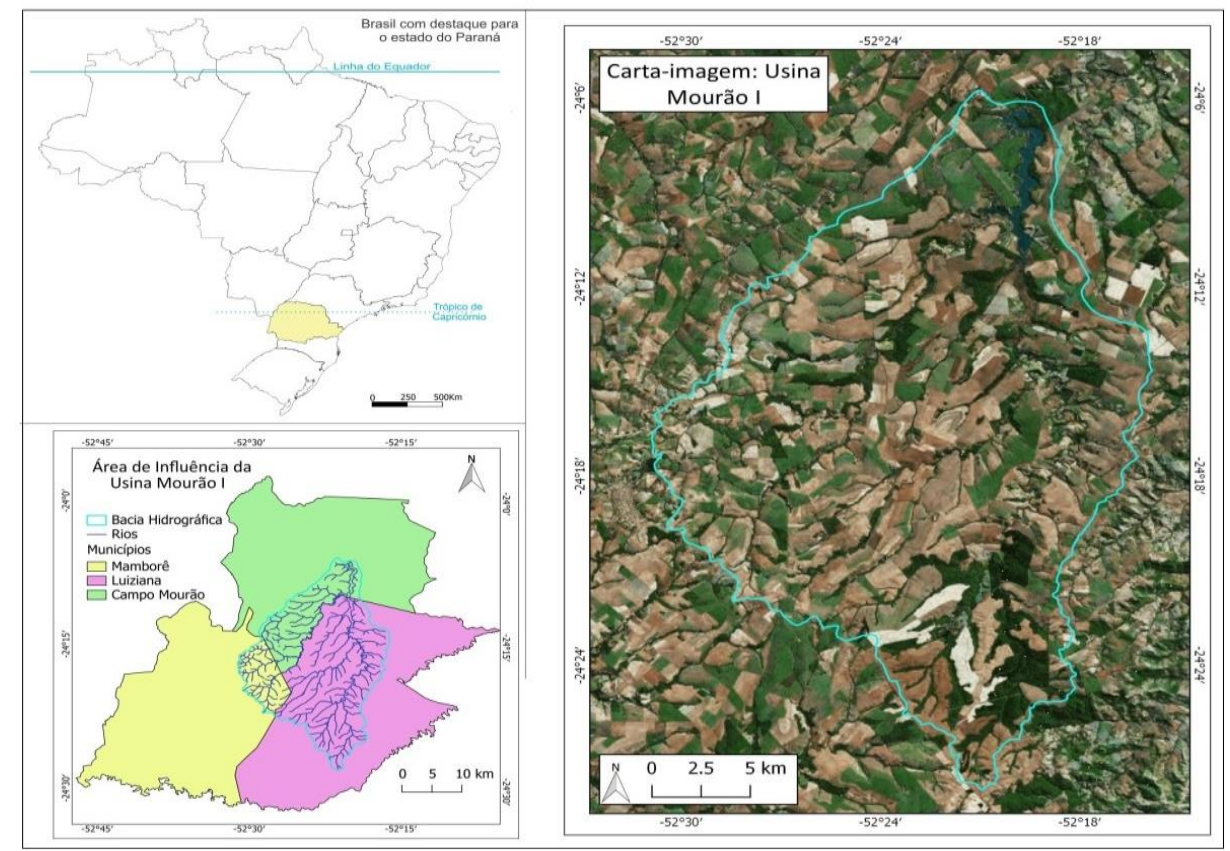

Fonte: Vetores com a delimitação política extraídos de IBGE (2015); Rede de drenagem e bacia hidrográfica de cartas topográficas; Imagem de Satélite da Plataforma Bing Maps (Earthstar Geographics, 2014). 
A construção da pequena central hidrelétrica Mourão I, teve origem a partir de sua idealização, em 1949, quando o Governo Estadual pediu concessão ao Governo Federal para o aproveitamento do potencial hídrico do Rio Mourão, a partir da queda d'água do Salto São João (antiga usina que preserva suas ruínas no Parque Estadual Lago Azul, representadas na Figura 2). Sua construção foi concretizada no ano de 1964 (Figura 3), com um potencial energético de $8.500 \mathrm{KW}$, distribuídos atualmente para a rede estadual (RELATÓRIO AMBIENTAL COPEL, 1999). Durante 30 anos, a concessão da usina pertenceu à Companhia Paranaense de Energia - COPEL, sendo atualmente administrada pela empresa italiana Enel Green Power Mourão S. A.

Figura 2 - Ruínas da Antiga Usina Salto São João no Parque Estadual Lago Azul, município de Campo Mourão

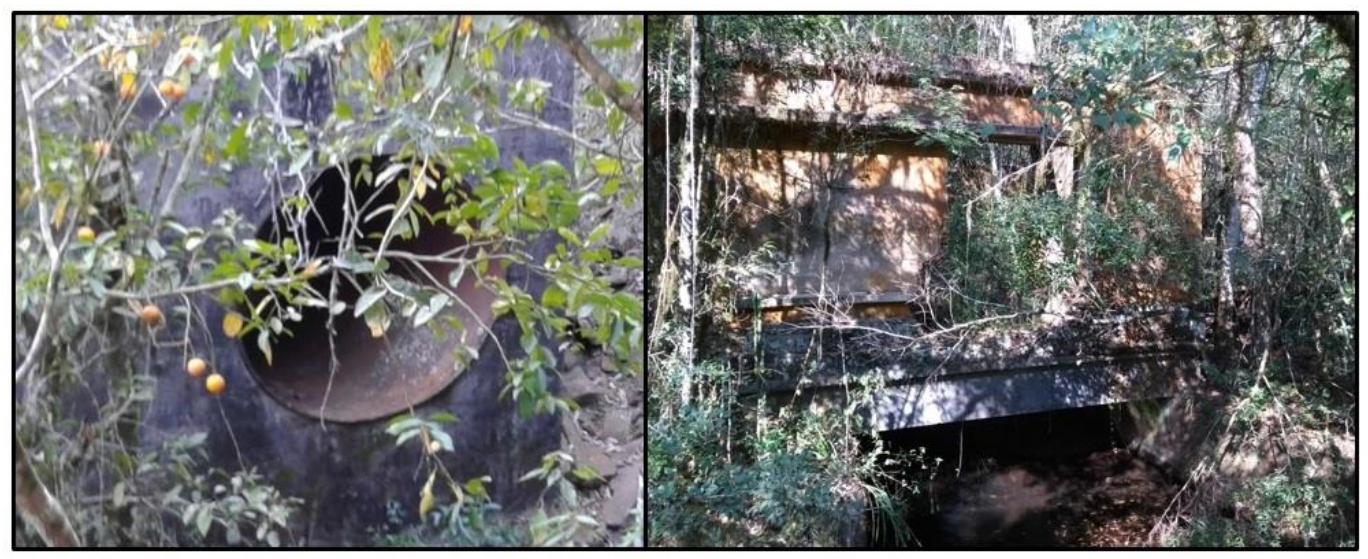

Fonte: Dienifer Fernanda dos Santos, 2017.

Figura 3 - Usina Mourão em fase de construção nas décadas de 1950 e 1960

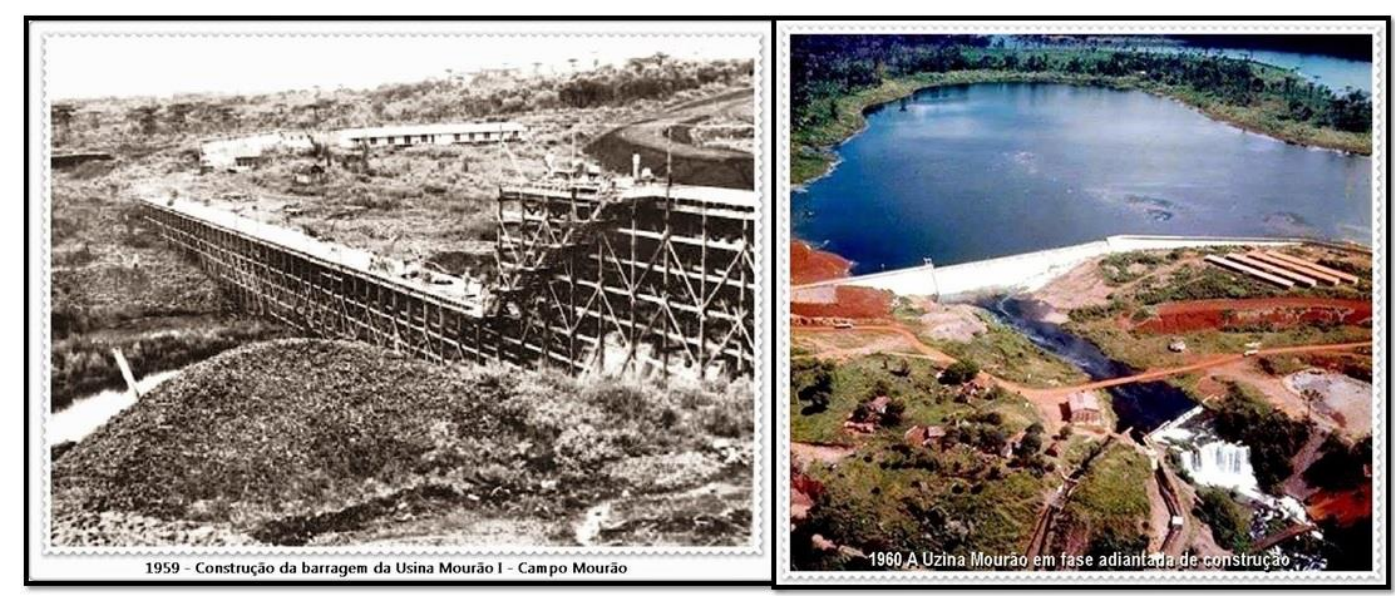

Fonte: BATHJE JR, W. Blog do Wille Bathke Jr. Campo Mourão, 2015. Disponível em: http://wibajucm.blogspot.com/. Acesso em: 10 jan. 2019. 
Os impactos ambientais produzidos na paisagem regional, decorrentes do barramento do curso hídrico, inundação das áreas circundantes, queima e desmatamento florestal, deram origem ao Parque Estadual Lago Azul - PELA, que se encontra situado a jusante da barragem da usina Mourão I. O parque foi criado como uma medida mitigatória por meio do Decreto Estadual n 3256, de 30 de junho de 1997, o qual abrange toda a área do reservatório até sua cota máxima, acrescida pela Área de Preservação Permanente - APP que, somadas, totalizam uma área de 1.749 hectares, com o objetivo de conciliar a proteção integral da fauna e da flora, com atividades educativas, recreativas e científicas (MINISTÉRIO DO MEIO AMBIENTE, 1997).

Com base na fotografia aérea da década de 1980 (Figura 4), evidencia-se que o entorno do lago já havia sido loteado, mas que ainda não havia um quantitativo significativo de residências construídas. No planejamento de ocupação dessa área, no limite dos lotes, foi construída uma via que separa as chácaras da área agrícola e que é utilizada correntemente para o trânsito entre as chácaras. Observa-se ainda que uma parte da vegetação do PELA, na margem direita do lago, encontrava-se mais densa e um pouco mais afastada, em regeneração.

De acordo com o Plano Diretor Municipal de Campo Mourão, “Com a construção da Usina o reservatório tornou-se de grande potencial turístico motivando o parcelamento do solo para fins urbanos nas margens da represa" (PREFEITURA MUNICIPAL DE CAMPO MOURÃO, 2007, p. 54). Embora o reservatório esteja inserido na área rural e as características de uso de seu entorno reflitam esse uso, a construção da Usina e o represamento do rio, bem como as posteriores transformações de seu entorno, resultaram no reenquadramento de parcela desse território como área urbana, promovendo a valorização econômica do espaço e ampliação da especulação imobiliária. 
Figura 4 - Fotografia aérea de 1980 demonstrando a área já loteada, porém ainda com poucas construções.

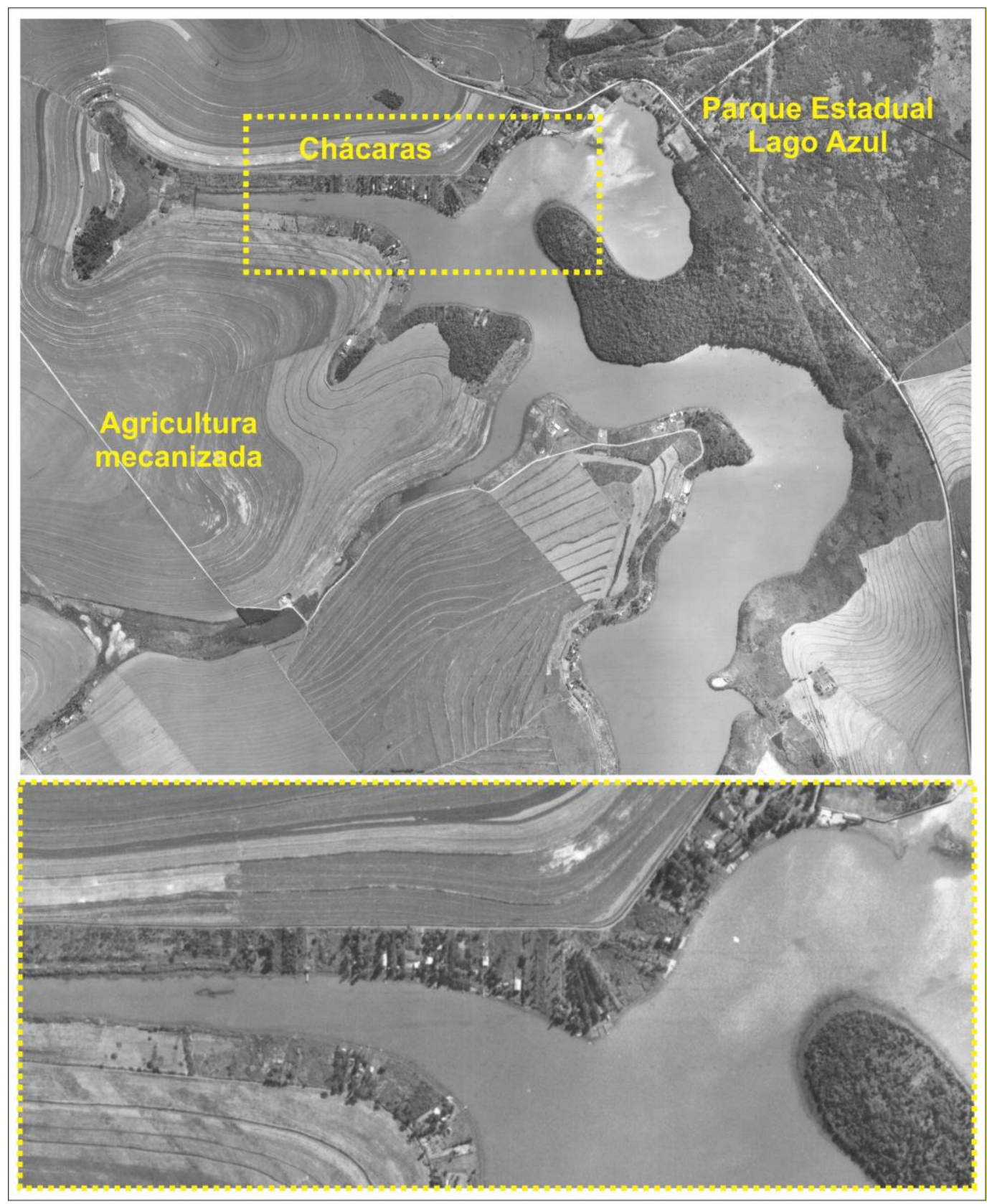

Fonte: SECRETARIA DO MEIO AMBIENTE E RECURSOS HÍDRICOS. ITCC - Instituto de Terras, Cartografia e Geociências. Levantamento aerofotogramétrico do estado do Paraná. Curitiba: ITGC, 1980.

Se, por um lado, a dinâmica da paisagem natural foi prejudicada pela construção da Usina Mourão I, por outro, o lago passou a atrair visitantes, estabelecendo uma nova dinâmica que, a priori, fora caracterizada como um ambiente de baixo valor aquisitivo e que, no correr dos anos, passou a atrair investidores de maior poder aquisitivo. Além disso, a nova paisagem gerou uma expectativa de ocupação diferente do que até então 
se observava, constituindo um patrimônio natural pela existência do PELA, de grande potencial turístico e de recreação (INSTITUTO AMBIENTAL DO PARANÁ, 2005; MASSOQUIM; AZEVEDO; SANTOS, 2007).

\section{O reservatório da Usina Mourão I e a multifuncionalidade do seu entorno}

O reservatório da Usina Mourão I abrange área de $11,3 \mathrm{~km}^{2}$, formado na confluência dos rios Mourão e Sem Passo, compreendendo área total de drenagem de $612 \mathrm{~km}^{2}$. O principal tipo de uso da terra é a agricultura temporária $\left(376 \mathrm{~km}^{2}\right)$, predominando as monoculturas de soja (primavera/verão), trigo e milho (outono/inverno), seguido pelas áreas de florestas $\left(141 \mathrm{~km}^{2}\right)$. Observa-se que os remanescentes de vegetação nativa estão associados às Áreas de Preservação Permanente e de Reserva Legal. Destacam-se também com expressão quantitativa as áreas de pastagens $\left(56 \mathrm{~km}^{2}\right)$, conforme pode ser observado na Figura 5. O solo exposto $\left(6 \mathrm{~km}^{2}\right)$ representa áreas em fase de transição de plantios agrícolas e as sedes de fazendas foram consideradas as propriedades rurais que apresentam áreas significativas com infraestrutura de médio e grande porte $\left(2 \mathrm{~km}^{2}\right)$.

Também fazem parte dessa paisagem áreas de silvicultura $\left(7 \mathrm{~km}^{2}\right)$, notadamente com o plantio de eucalipto, além do Parque Industrial da Coamo $\left(1 \mathrm{~km}^{2}\right)$. Destaca-se que parcela significativa das áreas de silvicultura são de domínio da Coamo e utilizadas nas caldeiras para geração de energia na produção agroindustrial. No mapeamento foram contabilizadas áreas de estradas $\left(7 \mathrm{~km}^{2}\right)$ e áreas urbanas e/ou de lazer $\left(4 \mathrm{~km}^{2}\right)$. Dentre as áreas urbanas, tem-se a cidade de Luiziana, os novos loteamentos e a área já consolidada no entorno do lago, estes dois últimos são o objeto deste estudo. 
Figura 5 - Mapa de Uso da Terra da Área de Influência da Usina Mourão I

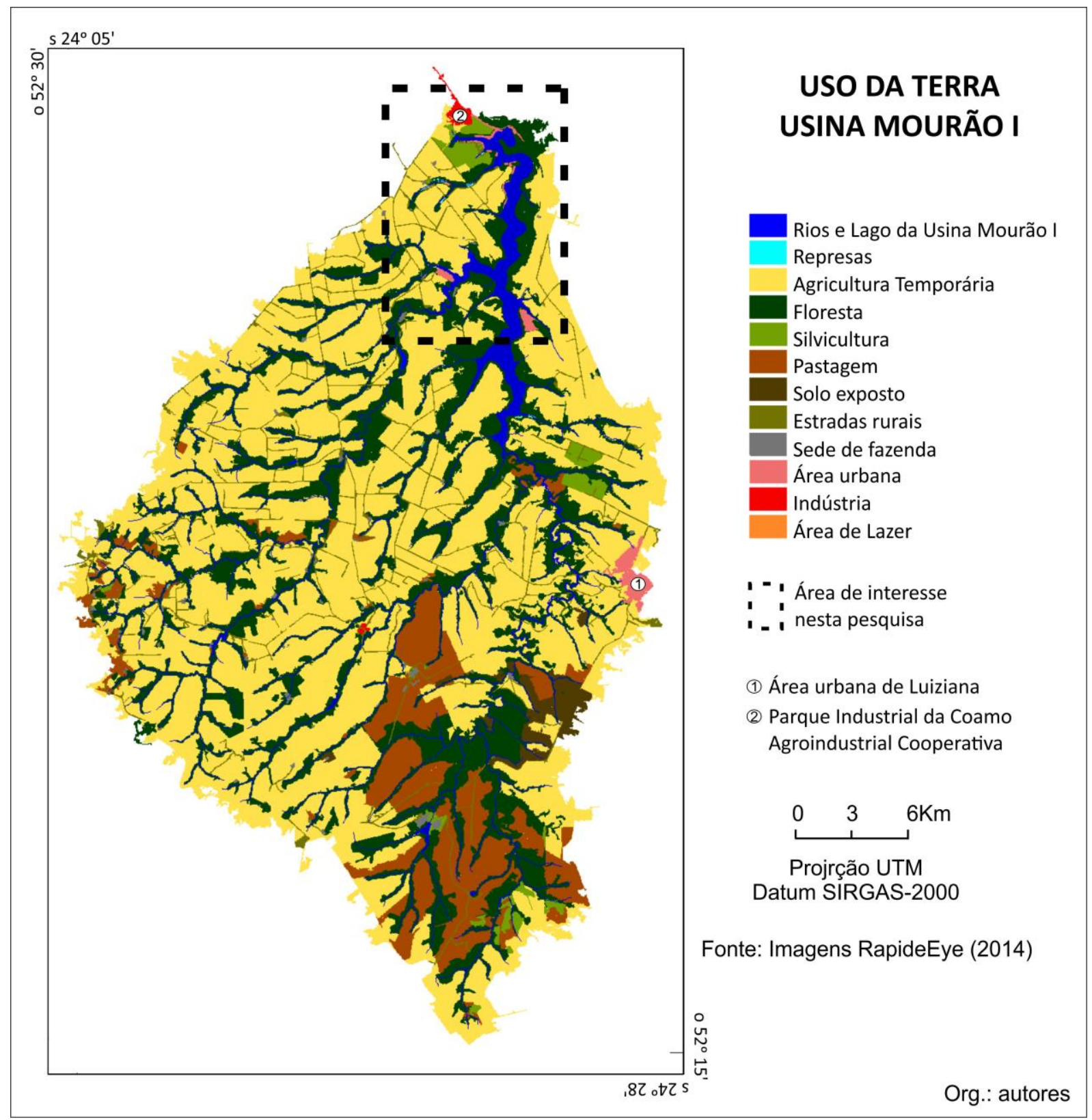

Fonte: RAPIDEYE. Distrito Federal: Ministerio do Meio Ambiente. Geo Catálogo, 2014. Imagem de satélite.

A construção da hidrelétrica transformou a paisagem local e requalificou seu uso. Hoje está configurada a partir da combinação de sobreposição de diferentes usos. Além disso, o espaço passou a apresentar multifuncionalidades, especialmente vinculadas ao lazer e à recreação, decorrentes da apropriação dessa nova paisagem.

Com relação aos espaços de uso recreativo e de lazer, presentes no entorno da usina, os dividimos em quatro categorias principais: 1) Chácaras urbanas com estrutura já 
consolidada; 2) Novos loteamentos e condomínios; 3) Espaços populares e privados de uso coletivo; 4) Parque Estadual Lago Azul - PELA, uma unidade de conservação de uso coletivo.

Considerando que a dinâmica vivenciada no entorno do reservatório da usina está promovendo a valorização monetária das propriedades, identificou-se um outro ponto de interesse na análise que consiste nas chácaras rurais e moradias de menor poder aquisitivo. Entende-se que elas ainda não passaram pela transição e apropriação com a refuncionalização de seu uso mas que, decorrente da pressão do capital, podem vir a ser incorporadas à lógica do mercado imobiliário e transformadas em chácaras de lazer.

\section{Chácaras urbanas com estrutura já consolidada}

As chácaras urbanas com estrutura já consolidada (Figuras 6 a, b, c e d) situam-se especialmente na porção noroeste do lago, na margem esquerda, próximas à barragem. Nos últimos anos houve significativo aumento do número de construções nessa área (Figuras 6 a e b). Essa localidade é definida pela Prefeitura Municipal de Campo Mourão (2014), como Zona de Urbanização Específica 4 - ZUE4 de Chácaras de Recreio, de acordo com a Lei Complementar $n^{\circ}$ 31, de 17 de Julho de 2014, que "Dispõe sobre o zoneamento de uso e ocupação do solo urbano e rural do município de Campo Mourão e dá outras providências".

As chácaras situadas nesse setor do reservatório são consideradas de alto padrão, utilizadas para moradia e/ou lazer nos finais de semana e feriados, muitas com piscina e campinho de futebol (Figuras 6 c e d). Preservam uma arquitetura mais sofisticada e moderna, além de serem de fácil acesso, nas proximidades da rodovia BR-487. Os padrões arquitetônicos da maioria dos imóveis expõem o padrão social de pessoas que têm acesso privilegiado ao ambiente aquático. Atualmente, a maioria dessas propriedades pertence a pessoas da elite mourãoense, composta especialmente por empresários e fazendeiros.

Desse modo, os empreendimentos imobiliários vêm selecionando a classe social que usufrui desse ambiente, pois até mesmo as chácaras mais modestas se situam sobre terrenos valorizados e requisitados. Dada a classificação do solo urbano e a proximidade 
do lago, o local vem constituindo um padrão econômico e imobiliário inacessível à classe proletária que, com muito esforço, consegue alugar uma chácara para passar o final de semana e ter o lazer desejado como qualquer cidadão.

Figura 6 - Área de chácaras já consolidadas no entorno do reservatório da Usina Mourão I. a) Localização das chácaras em 2003 b) evolução das construções - 2019 c) residências próximas ao lago d) parte interna de uma das residências
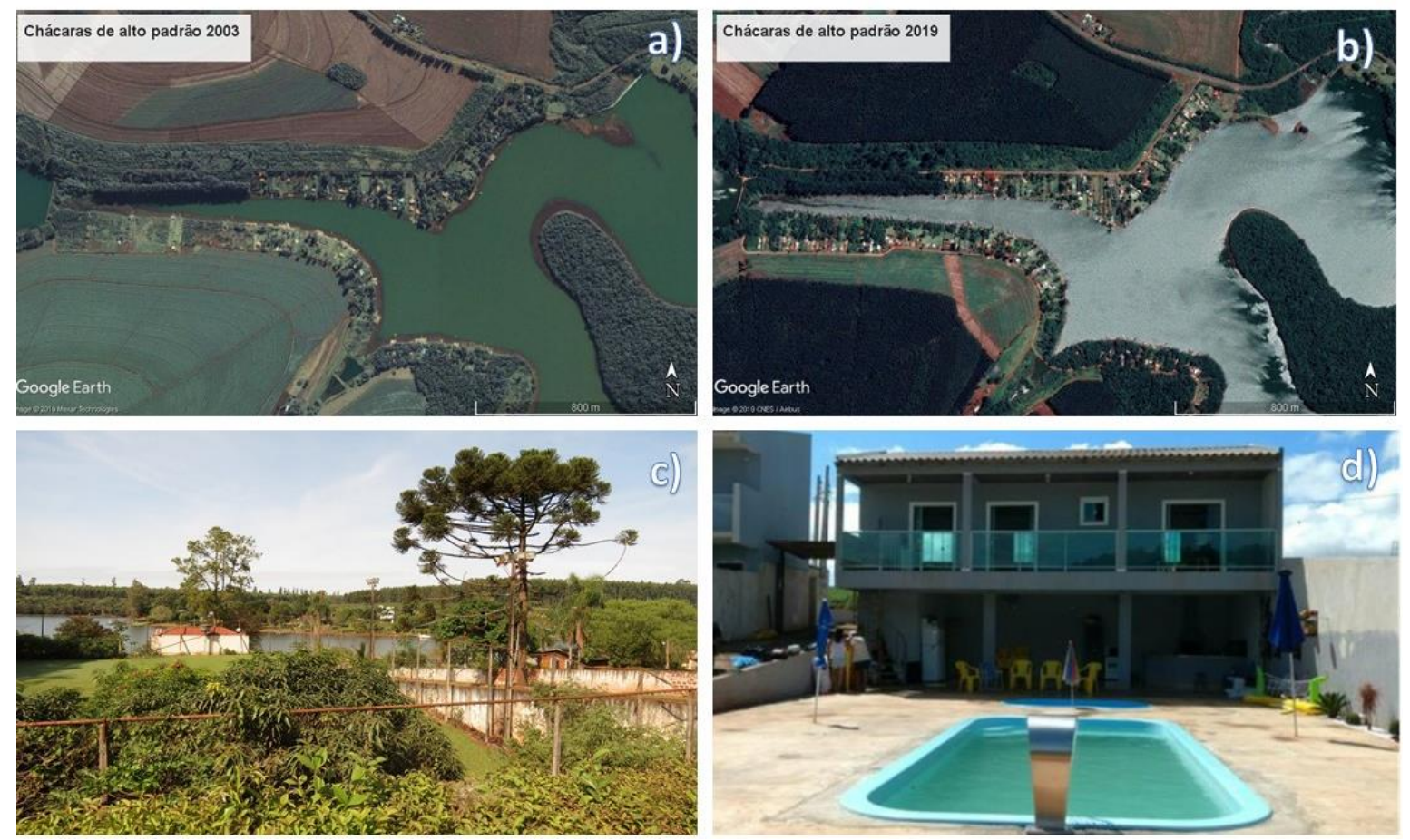

Fonte: A e B: GOOGLE. Google Earth Pro 2018. Imagens de Satélite. C e D: Fotografias de Adriano Ferreira Guimarães, 2019.

Portanto, sendo essa uma área urbanizada peculiar, de contato direto com a água e distante dos estresses citadinos comuns, vivenciados no dia-a-dia, o lago da usina tornou-se um dos lugares mais procurados da região para praticar o lazer e a recreação nos finais de semana. São exemplos de práticas realizadas no reservatório pelos frequentadores deste espaço: navegação com lancha, jet-ski, barco e veleiro; passeios de caiaque e pedalinho; pesca esportiva e natação.

Essa parte ocupa aproximadamente $10 \mathrm{~km}$ de margem no entorno do lago, com propriedades de tamanhos variáveis, especialmente entre um e cinco mil metros quadrados. Com relação à preservação ambiental, nem todas obedecem à legislação 
brasileira que especifica a área de mata ciliar. Conforme pode ser observado na Figura 7, na maioria das propriedades estão presentes trapiches que adentram a área do reservatório. Destaca-se que o parcelamento do solo e a venda dos lotes está se expandindo para uma área anteriormente considerada menos nobre da Usina - o braço do lago.

Figura 7 - Imagem representativa das chácaras de lazer de alto padrão no Entorno do Reservatório da Usina Mourão I

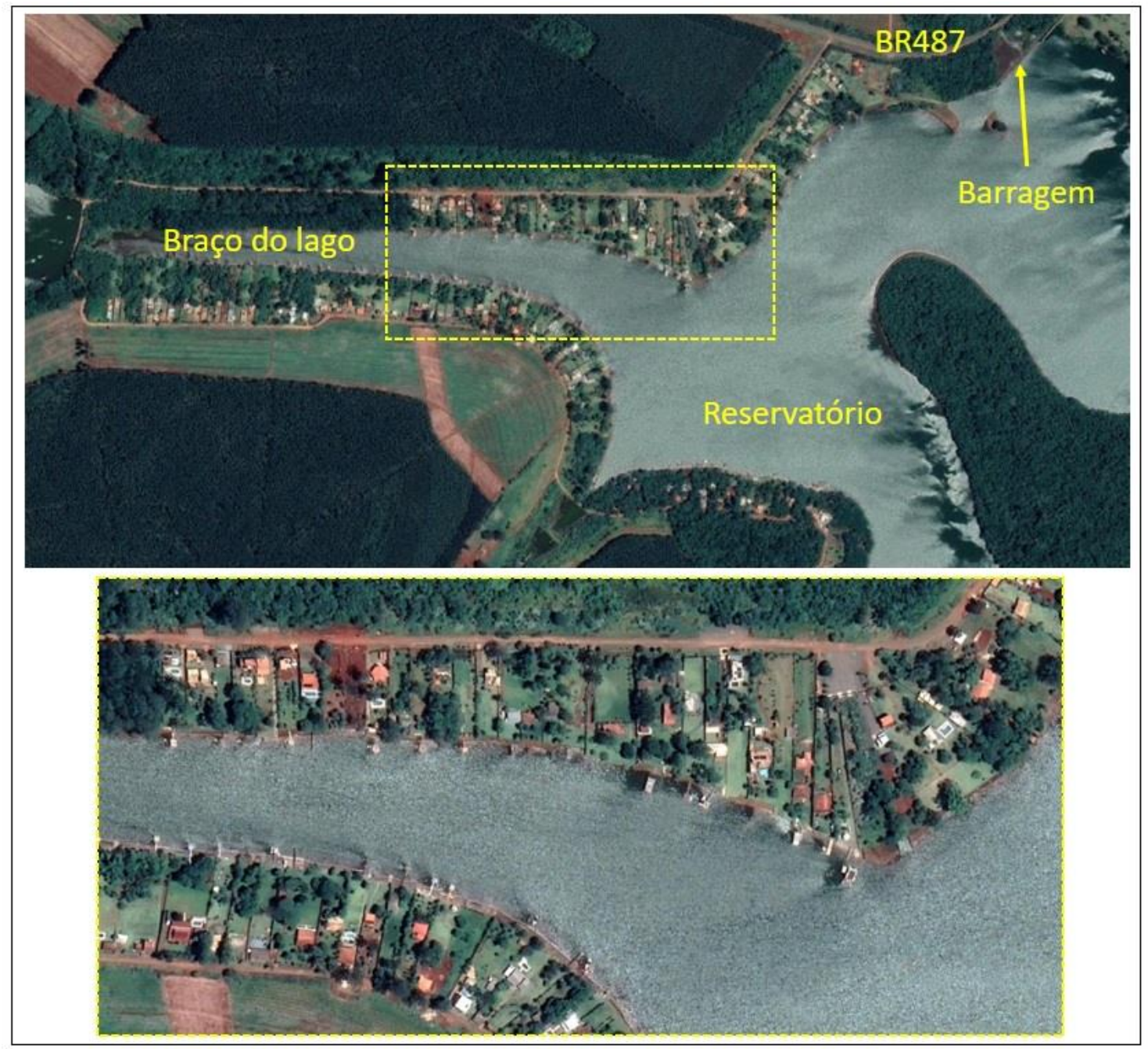

Fonte: GOOGLE. Google Earth Pro 2018. Imagens de Satélite.

\section{Novos loteamentos e condomínios}

Com relação aos novos loteamentos e condomínios (Figura 8), denominados de Quinta dos Mourões (Figuras 8 a, b e c) e Balneário Veleiro (Figuras 8 d, e, f, g, h e i), 
ambos situados na porção leste do reservatório, eles instituem uma paisagem ainda mais restrita e distante da classe proletária dada a magnitude de alcance direcionada à classe de alto poder aquisitivo.

O Balneário Veleiro, com seus lotes parcelados e em fase de construção, ocupa uma área de aproximadamente 52 hectares, dos quais aproximadamente 35 hectares são destinados aos lotes. No Balneário, foram respeitados os 100 metros de mata ciliar, com a vegetação em fase de regeneração. Antes do loteamento, essa porção de terra fazia parte de uma propriedade rural. Um terreno de $1.000 \mathrm{~m}^{2}$, de acordo com anúncio da OLX, está avaliado em $\mathrm{R} \$ 95.000,00$. Já existem residências construídas e em algumas propriedades foram construídas piscina e edícula, utilizadas pelos proprietários ou em regime de aluguel por diária, destinadas, portanto, ao lazer e à recreação. Está presente também uma rampa para descarga e recolhimento das embarcações que adentrarão as águas do lago.

Figura 8 - Novos loteamentos localizados no entorno do reservatório da Usina Mourão I.

a) Imagem de satélite do condomínio fechado Quinta dos Mourões b) Entrada do condomínio c) Imagem de Satélite do condomínio fechado Balneário Veleiro d)

Panorâmica do Balneário e) Maquete estrutural do balneário f) Entrada do balneário g) Fonte da entrada do condomínio h) Marina privativa do condomínio

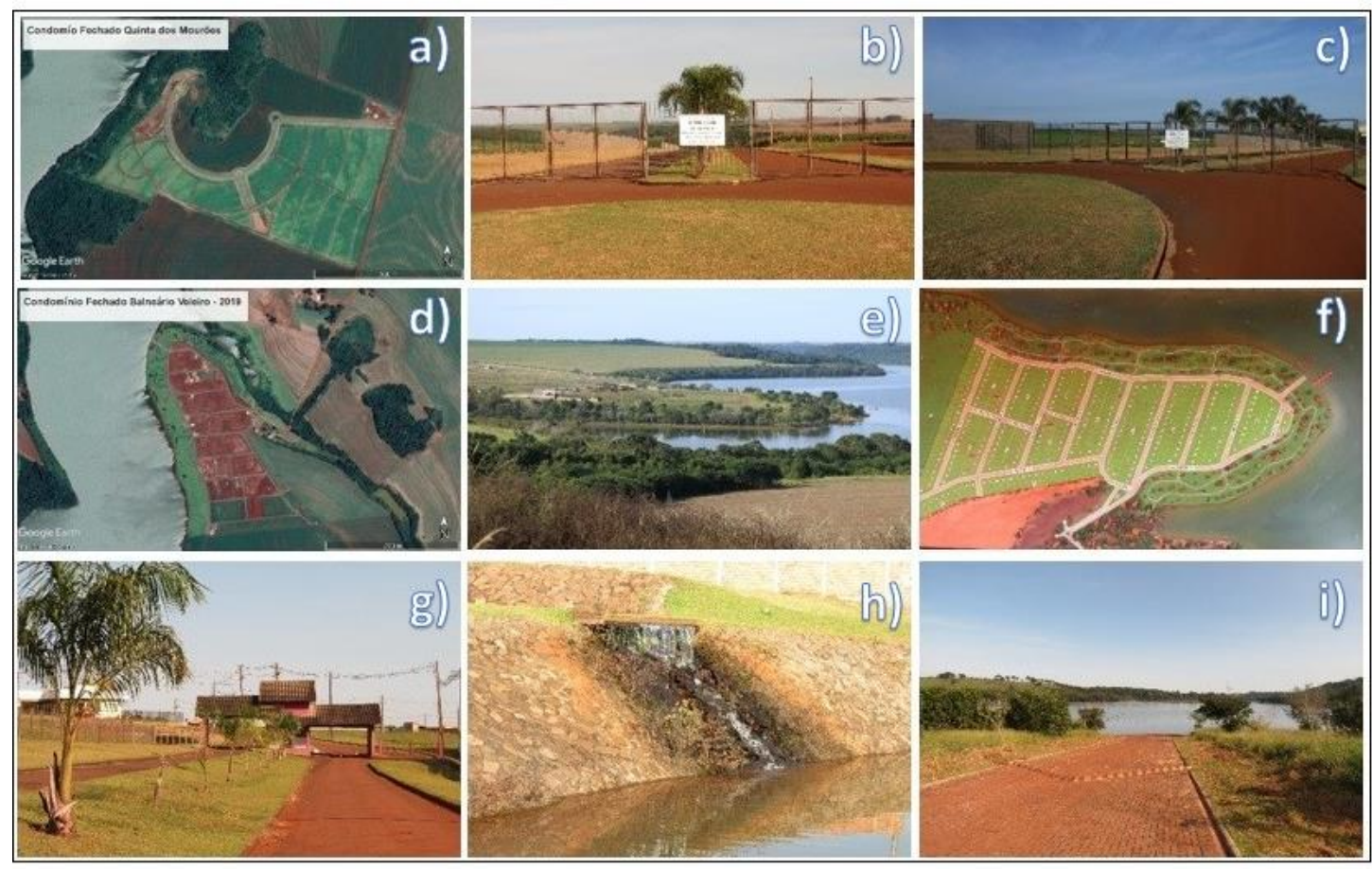

Fonte: A e D: GOOGLE. Google Earth Pro 2018. Imagens de Satélite. B, C, E, F, G, H e I: Fotografias de Adriano Ferreira Guimarães, 2019. 
Já o condomínio Quinta dos Mourões, compreenderá em seu próprio espaço diferentes paisagens de lazer e recreação como, por exemplo, a implantação de um condomínio residencial, um clube, um Eco resort e uma marina permitindo o acesso de embarcações (lanchas) ao reservatório, os quais serão instalados sobre uma área de aproximadamente 72 hectares nas bordas do lago. Destaca-se que os lotes desse condomínio ainda não foram liberados para construção pois há conflito de interesses e um processo em andamento, uma vez que o loteamento se estende por parte do território que pertence ao Parque Estadual Lago Azul.

Caso o funcionamento do condomínio seja aprovado e as obras tenham continuidade, os novos loteamentos contribuirão ainda mais com a valorização do solo e especulação imobiliária no entorno do reservatório da Usina Mourão I. Decorrente dos altos valores e da infraestrutura prevista no projeto de construção do condomínio, esse espaço se caracteriza como segregativo, que atende aos ditames do capital, proporcionando lazer a uma minoria rica. Destaca-se que na propaganda de venda dos lotes, a proximidade com a natureza é fator de forte relevância e a paisagem se torna, portanto, um elemento apropriado pela publicidade e pelo marketing.

\section{Espaços populares e privados de uso coletivo}

$\mathrm{Na}$ área pesquisada também estão presentes espaços de uso coletivo que foram subdivididos em populares e privados (Figura 9). Dentre os espaços privados, destacamse o Cayenna Club, situado na porção norte do reservatório (Figuras 9 c e d) e o Pesqueiro Três Irmãos na porção sudoeste (Figuras 9 e e f). Já os espaços populares de uso coletivo são aqueles que fazem parte de áreas de domínio público e que são utilizados pela população que não tem acesso às chácaras ou aos espaços privados de lazer. Os mais conhecidos são o “Beco” (Figura 9b) e o "Paliteiro” (Figuras 9 g e h).

O Cayenna Club é um empreendimento do ramo de restaurantes, situado na porção norte do reservatório, entre as chácaras de lazer já consolidadas. Caracteriza-se como um espaço elitizado e seletivo. Oferece entretenimento ao ar livre, com vista para o lago e diferentes paisagens, dentre elas a natural, composta por vegetação do PELA e a paisagem construída que abriga as chácaras. 
Atualmente, o empreendimento promove diferentes eventos festivos, como festas, shows de duplas sertanejas nacionais, shows com música eletrônica, pagode, dentre outros estilos musicais. Além disso, o Cayenna Club proporciona diferentes tipos de ambientes, dentre eles se destacam um espaço reservado para churrasco e uma rampa de acesso à água para os clientes descarregarem lanchas e jet-skis.

O pesqueiro Três Irmãos, situado na porção sudoeste, é um ambiente que foi criado como um "pesque e pague", mas que passou a desenvolver espaços para recreação aquática em piscinas artificiais com tobogãs, parquinho para as crianças, campo de futebol, ambiente aquático com tartarugas e peixes ornamentais, área para churrasco e restaurante. Durante o verão recebe um quantitativo significativo de usuários, cobrando valor popular da diária para uso das dependências da piscina, parque e churrasqueira.

Outros usos recreativos identificados, na área pesquisada, enquadram-se na categoria de espaços populares de uso recreativo não privado (Figura 9). Essa categoria contempla pequenos lagos, situados nas proximidades das vias de circulação, áreas conhecidas como "beco" ou "paliteiro". Nesses espaços, predomina a pesca rudimentar, utilizando-se de vara, anzol e iscas caseiras, mas em alguns casos já existe o uso de molinetes e outros equipamentos mais modernos.

Entretanto, o ato de pescar nesses espaços isolados, considerados como populares, criados e apropriados pela população que é privada de uso dos espaços mais nobres, inspiram cuidados quanto ao acesso e ao uso do local. Os usuários costumam acampar e fazer fogueiras improvisadas, expondo-se ao risco e colocando a própria vegetação do entorno em risco. 
Figura 9 - Espaços populares e privados de uso coletivo. a) Imagem de Satélite da Localização dos espaços privados de uso coletivo b) Imagem de satélite da localização do Beco c) Imagem de satélite da localização do Cayenna Clube d) Imagem da entrada do Cayenna Club e) Imagem de satélite do Pesqueiro Três Irmãos f) Panorâmica do parque aquático do pesqueiro g) Imagem de satélite da localização do Paliteiro h) Paliteiro

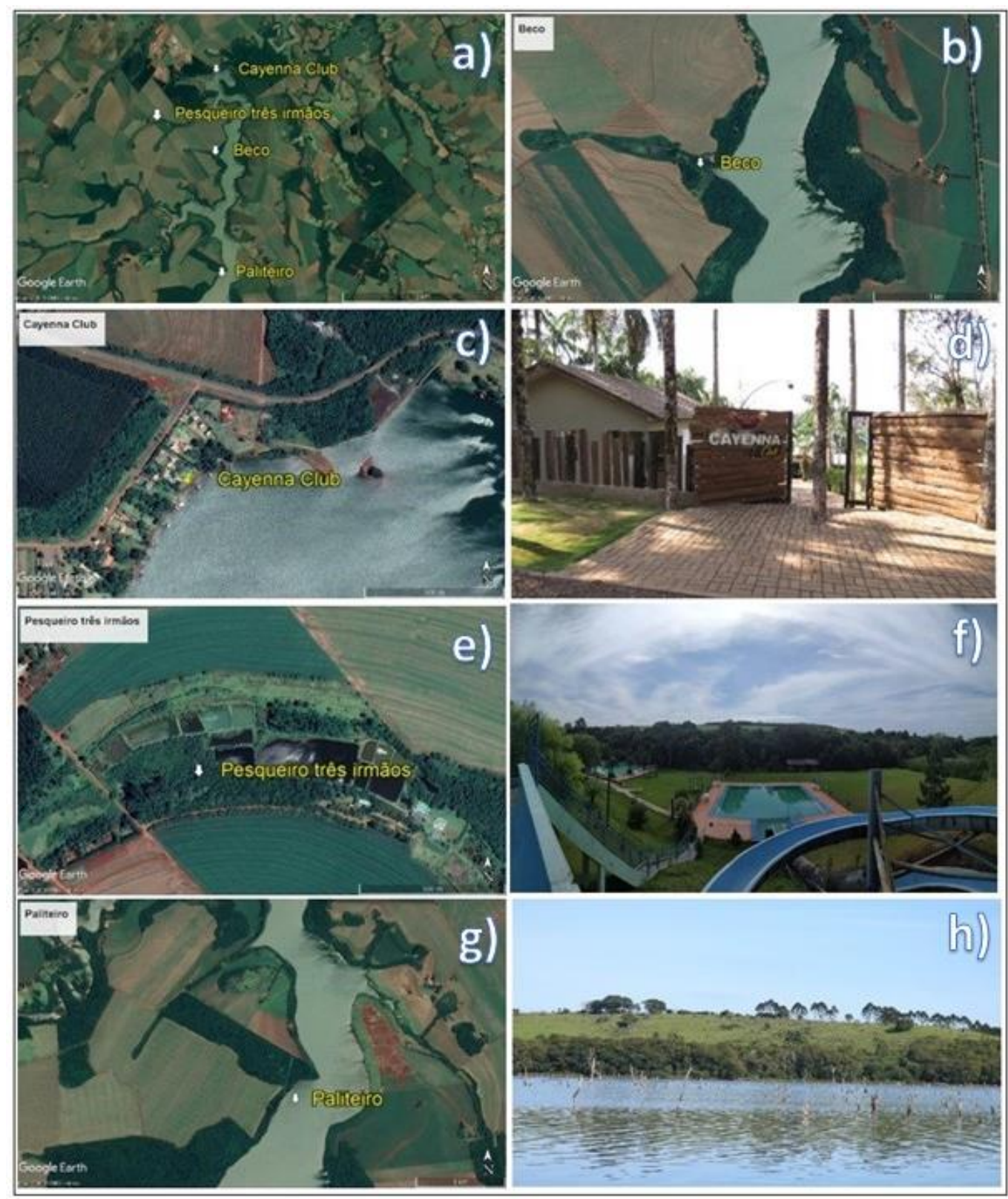

Fonte: A, B, C, E e G: GOOGLE. Google Earth Pro 2018. Imagens de Satélite. D, F e H: Fotografias de Adriano Ferreira Guimarães, 2019.

Além da pesca rudimentar, vem se desenvolvendo a pesca amadora com grupos organizados para esse fim. Eventos esporádicos são planejados por entidades civis, com a participação de setores do governo municipal e estadual, tais como a soltura de peixes, a 
realização de práticas esportivas no lago, atividades de educação ambiental e campeonato de pesca amadora (Figura 10). Esses eventos atraem a participação da população, local e regional.

Figura 10 - Prática esportiva com caiaque, campeonato de pesca amadora e soltura de alevinos

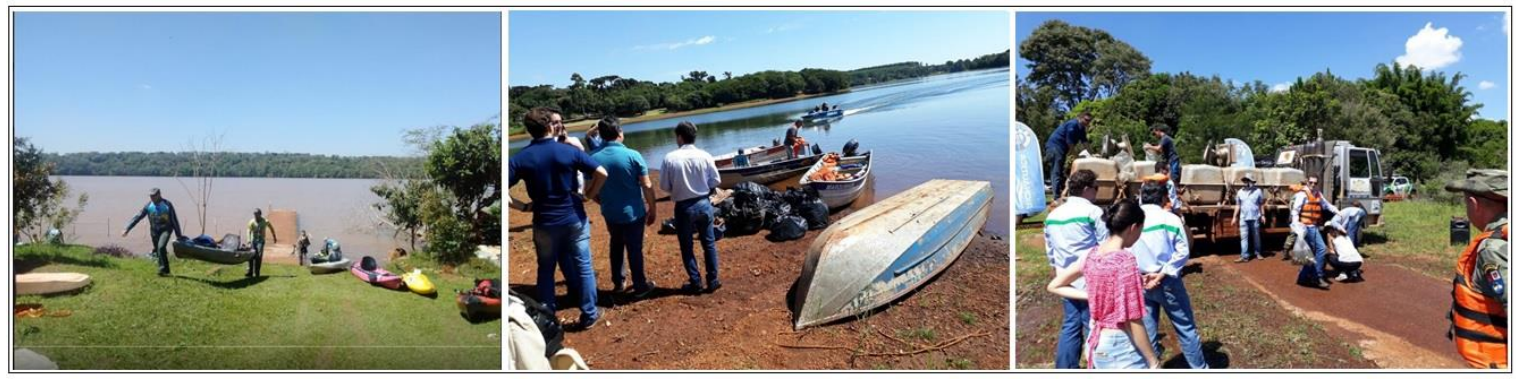

Fonte: A: LORENZO, F. Usina Mourão sediou Torneio de Pesca com Caiaque e Canoa. TaSabendo. Campo Mourão, 2016. Disponível em https://tasabendo.com.br/geral/usina-mourao-sediou-torneio-de-pesca-comcaiaque-e-canoa/. Acesso: 20 abr. 2019. B e C: Fotografias de Ubirajara Eduardo Colavite.

\section{Parque Estadual Lago Azul - PELA - unidade de conservação de uso coletivo}

Outra categoria classificada como de uso comum é o Parque Estadual Lago Azul (PELA), uma Unidade de Conservação, sendo ele um dos poucos espaços aberto ao público na área de abrangência da usina (Figura 11). Ele foi criado como medida compensatória pelo represamento do rio Mourão e é procurado o ano inteiro, especialmente por escolas da região para a realização de aulas de educação ambiental.

Essa categoria proporciona a prática do lazer e da recreação em 2 (duas) trilhas. A primeira é denominada Trilha Peroba; com uma extensão de 3.850 metros, é explorada em seus aspectos físicos e biológicos, de modo interpretativo, pelos visitantes que observam distintas formações vegetais, passando por uma cascata, e pelo lago que deu origem ao nome do parque. A segunda trilha, denominada Trilha Aventura, com uma extensão de 3.500 metros, é composta por obstáculos naturais, percurso realizado pelo Rio Mourão, visitação a 2 (duas) cachoeiras conhecidas por Salto Belo e Salto São João, e pelas ruínas da antiga Usina de Salto São João. Portanto, ambas as trilhas se destacam pela diversidade da fauna e da flora. 
Figura 11 - Parque Estadual Lago Azul - PELA. a) Imagem de satélite do Parque Estadual Lago Azul b) Recepção do Parque c) Entrada do parque d) Trilha principal e) Salto São João

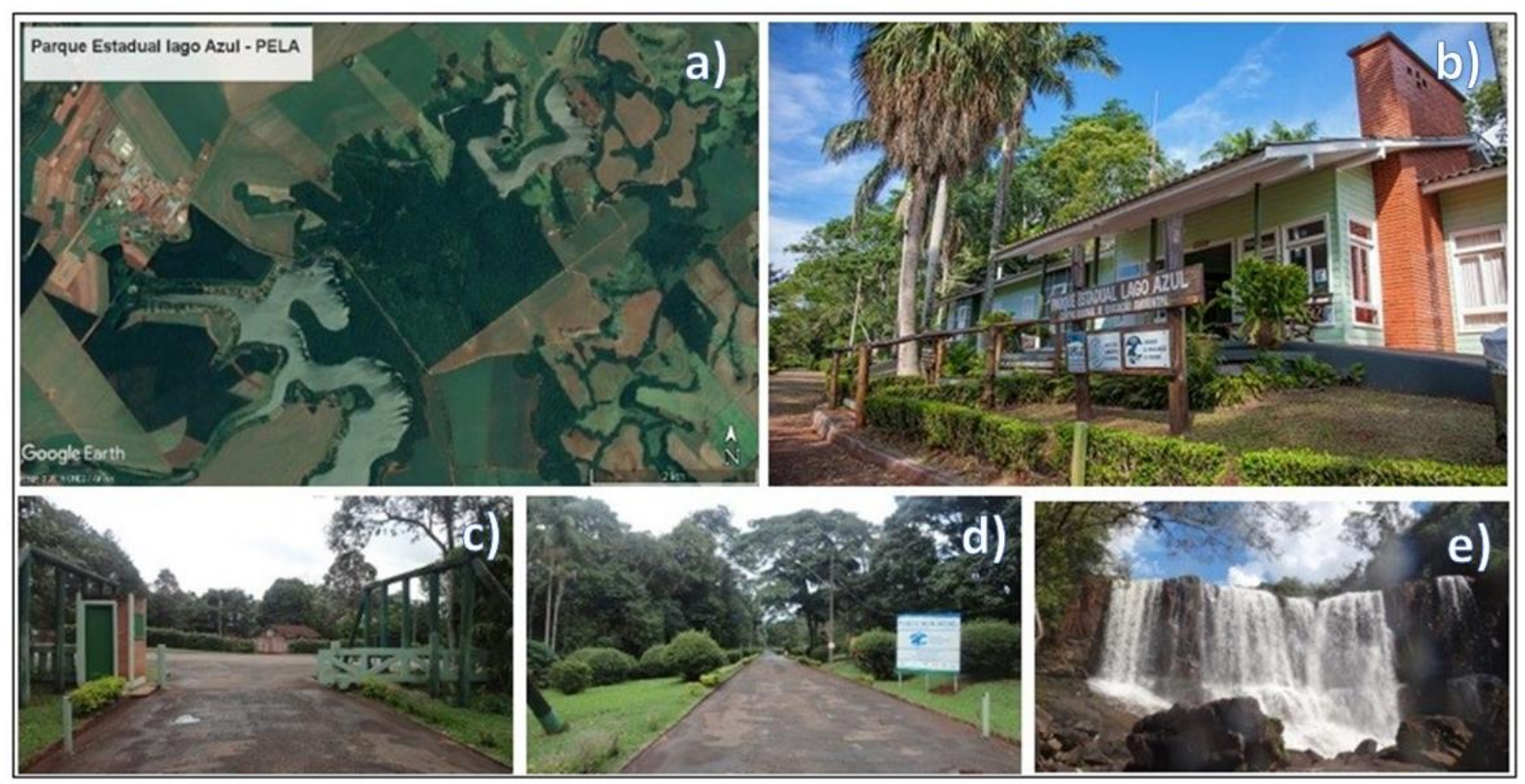

Fonte: A: GOOGLE. Google Earth Pro 2018. Imagens de Satélite. B, C e D: Fotografias de Dienifer Fernanda dos Santos, 2017.

Embora o PELA compreenda uma significância ambiental como uma unidade de conservação, e social para a prática do lazer e recreação, ainda é um lugar pouco visitado, principalmente pela população regional, dada a pouca divulgação social do parque.

\section{Chácaras rurais e moradias de menor poder aquisitivo, um espaço em transição}

As chácaras rurais e as moradias de pessoas de menor poder aquisitivo situam-se na porção sudoeste do reservatório (Figura 12 a), próximas à área onde o lago começa a ser formado (Figura 12 a). Nessa região, o uso do entorno é predominantemente rural e as propriedades apresentam infraestruturas mais simples (Figuras 12 b, c, d e e). Nelas estão presentes atividades de agricultura familiar, com práticas mais rústicas, bem como a criação de animais para o próprio consumo e venda local do excedente, mas sem expressão no comércio municipal. 
Figura 12 - moradias de menor poder aquisitivo em chácaras rurais. a) Imagem de satélite da localização das chácaras rurais. b), c), d), e) Residências rurais. f) Igreja católica da comunidade rural

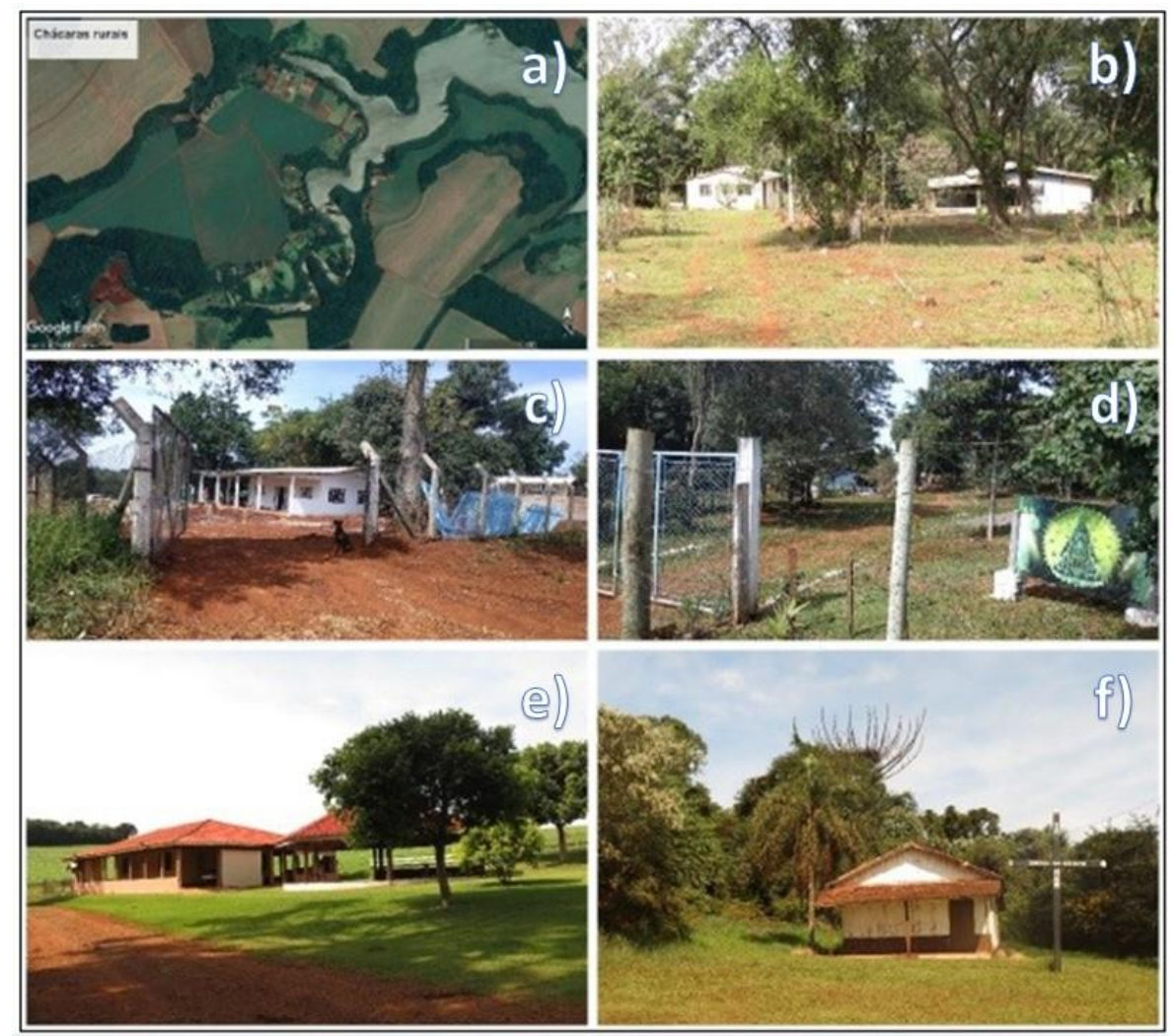

Fonte: a) GOOGLE. Google Earth Pro 2018. Imagens de Satélite. b), c), d), e), f) Fotografias de Adriano Ferreira Guimarães, 2019.

Essas chácaras são mais afastadas da Barragem, geralmente situadas em braços do reservatório, com relevo mais declivoso. O tamanho das propriedades também é maior do que os lotes da zona urbana, situada no entorno do reservatório, apresentando em média de 2 a 5 hectares. Destaca-se que alguns moradores dessa região trabalham eventualmente em propriedades agrícolas próximas ou, ainda, prestando serviço para outros proprietários de chácaras do entorno. Nas proximidades dessa área está presente uma Igreja Católica onde são celebradas missas quinzenais com a participação da comunidade que ali reside (Figura $12 \mathrm{f}$ ).

Embora essa região seja mais distante da rodovia e da área mais valorizada no entorno do Lago, foi possível observar que novas construções estão em andamento na região e também algumas propriedades estão disponíveis para aluguel, para finais de semana ou mensais, o que indica uma provável mudança futura no perfil de propriedades 
da região. Portanto, essa região foi considerada como um espaço em transição e que, muito em breve, pode vir a sofrer com a pressão do mercado imobiliário que já começa a visualizar nesses sítios a possibilidade de parcelamento do solo, com sua fragmentação e venda de chácaras.

\section{Considerações finais}

Com o desenvolvimento da pesquisa evidenciou-se que, no entorno do reservatório da Usina Mourão I, após o alagamento da área, inúmeras transformações na paisagem foram registradas. A nova configuração do ambiente, que passou a contar com um reservatório de águas, foi o principal vetor para a ampliação da diversificação dos tipos de uso da terra e, consequentemente, a mulfuncionalização do espaço.

A Instalação da usina hidrelétrica, além de ser uma obra de engenharia que alterou a paisagem local, interferiu também no interesse pela área, transformando-a de predominantemente rural para uma área urbana de uso especial.

Identificou-se também que a paisagem é objeto de apropriação e tem forte influência na valorização dos imóveis locais; a sensação de proximidade com a natureza é fator de relevância para quem busca frequentar o entorno do reservatório. Entretanto, esses espaços de lazer e recreação se desenvolvem com maior intensidade para um grupo de maior poder aquisitivo que possui imóveis de médio e alto padrões.

O reservatório tem sido amplamente utilizado para práticas de lazer. Entretanto, nem sempre estão visíveis práticas de conservação da natureza, tais como a manutenção e/ou recuperação da área de mata ciliar. A exceção do PELA e de Reservas Particulares do Patrimônio Natural (RPPN) que mantêm a vegetação preservada.

Com relação às chácaras rurais com moradias de menor poder aquisitivo, nesses espaços estão presentes trabalhadores que atendem demandas locais e que produzem gêneros alimentícios para o próprio consumo e comercialização para a vizinhança. Nesses espaços há uma tendência à valorização imobiliária. 


\section{Referências}

BATTY, Michael et al. Representing multifunctional cities: density and diversity in space and time. Built Environment, Londres, v.30, n. 4, p.324-337, dez. 2004.

CARVALHO, Daniel Fonseca de; SILVA, Leonardo Duarte Batista da. Introdução a hidrologia: usos múltiplos da Água. Rio de Janeiro: UFRRJ, 2006.

COELHO, Silvério José; PEREIRA, José Aldo Alves. A paisagem na área de influência da Usina Hidrelétrica do Funil (UHE-FUNIL), percebida através do EIA-RIMA. Paisagem ambiente: ensaios, São Paulo, n. 28, p. 133-148, 2011.

CONSELHO DE DESENVOLVIMENTO DOS MUNICÍPIOS LINDEIROS AO LAGO DE ITAIPÚ. Projetos: Santa Helena. Lindeiros: [s.n.], 2018. Disponível em: https://www.lindeiros.org.br/acoes-e-atividades. Acesso em: 13 ago. 2018.

CRUZ, Rita de Cássia Ariza. Lazer Turístico. In: CRUZ, Rita de Cássia Ariza. Introdução a geografia do turismo. 2 Ed. São Paulo: Roca, 2003.

DIAS, Gabriela Marcantônio; GRANADO, Danielli Cristina. Lazer e recreação associados aos ambientes aquáticos numa pequena cidade do interior paulista. Colloquim

Humanarum, Presidente Prudente, v. 11, n. especial, p. 678-686, 2014.

EARTHSTAR GEOGRAPHICS. World imagery. San Diego: Earthstar Geographics LLC, 2014. Imagens de satélite acessadas via plataforma Bing Maps.

FERREIRA, Roberta Celestino; LOPES, Wilza Gomes Reis; ARAÚJO, José Luís Lopes. A água como suporte para atividades de lazer e turismo: possibilidades e limitações da barragem Piracuruca no Estado do Piauí (Brasil). RA'E GA, Curitiba, n. 25, p. 134-163, 2005.

INSTITUTO AMBIENTAL DO PARANÁ. PLANO DE MANEJO. III Encarte. Análise do Parque Estadual Lago Azul. Curitiba, 2005.

\section{INSTITUTO BRASILEIRO DE GEOGRAFIA E ESTATÍSTICA. Bases e referenciais. Bases} cartográficas. Malhas digitais. Rio de Janeiro, 2015.

LONDE, Patrícia Ribeiro; MENDES, Paulo Cezar. A influência das áreas verdes na qualidade de vida urbana. HYGEA - Revista Brasileira de Geografia Médica e da Saúde, Uberlândia, v. 10, n. 18, p. $264-272$, jun. 2014.

LOPES, Frederico Wagner de Azevedo; CARVALHO, Alex de; MAGALHÃES JR, Antônio Pereira. Levantamento e avaliação dos impactos ambientais em áreas de uso recreacional 
das águas na bacia do Alto Rio das Velhas. Caderno Virtual de Turismo, Rio de Janeiro, v. 11, n. 2, p.177-190, ago. 2011.

LOPES, Frederico Wagner de Azevedo; JESUS, Cláudio Roberto de. Lazer e Balneabilidade: uma abordagem histórica sobre o uso recreacional das águas na sociedade. Caderno de Geografia, Belo Horizonte, v. 27, n. 50, 2017.

MASSOQUIM, Nair Glória; AZEVEDO, Tarik Rezende de; SANTOS, Adriana Mailkut dos. Estudo da Paisagem em Áreas Conflitivas no Entorno do Lago Azul. In: ENCONTRO DE GEÓGRAFOS DA AMÉRICA LATINA, 11., 2007, Bogotá. Anais [...]. Bogotá: Departamento de Geografia, 2007. v. 1. Tema: Geopolitica, globalización y cambio ambiental: retos en el desarrollo latinoamericano.

MINISTÉRIO DO MEIO AMBIENTE. Conselho Nacional do Meio Ambiente. Resolução CONAMA Nº 357, de 17 de Março de 2005. Dispõe sobre a classificação dos corpos de água e diretrizes ambientais para o seu enquadramento, bem como estabelece as condições e padrões de lançamento de efluentes, e dá outras providências. Brasília, DF: CONAMA, 2005.

MINISTÉRIO DO MEIO AMBIENTE. Instituto Chico Mendes de Conservação da Biodiversidade - ICMBIO. Decreto N$^{\circ} 3.256$ de 30 de Junho de 1997. Criado o Parque Estadual Lago Azul, localizado nos municípios de Campo Mourão e Luiziana no Estado do Paraná. Curitiba: ICMBIO, 1997.

NASCIMENTO, Flávio Rodrigues do. Categorização de usos múltiplos dos recursos hídricos e problemas ambientais. Revista ANPEGE, Rio Grande do Sul, v. 7, n. 1, p. 81-97, out. 2011. Número especial OLIVEIRA, Wallace de. Os impactos socioambientais motivados pela UHE de Porto Primavera no município de Anaurilândia - MS. Presidente Prudente: Universidade Estadual Paulista, 2004.

PEREIRA, Lilian Pena. Avaliação do uso do Lago Paranoá para atividades recreacionais. 2006. Dissertação (Mestrado em Recursos Florestais e Recursos Hídricos) - Faculdade de Tecnologia, Universidade de Brasília. Brasília, 2006

PERTILLE, Iara. O uso turístico dos reservatórios de hidrelétricas: estudo dos terminais turísticos no Lago de Itaipú, Paraná, Brasil. 2007. Dissertação (Mestrado em Turismo) Universidade de Caxias do Sul, Caxias do Sul, 2007.

PIACENTI, Carlos Alberto et al. Apontamento sobre a economia dos municípios atingidos pelas hidrelétricas de Salto Caxias e Itaipú Binacional. Revista Paranaense de desenvolvimento, Curitiba, n. 104, p.103-123, 2003. 
PREFEITURA MUNICIPAL DE CAMPO MOURÃO. Plano Diretor Municipal. Parques Públicos. Parque Estadual Lago Azul. Campo Mourão, 2007. p. 54.

PREFEITURA MUNICIPAL DE CAMPO MOURÃO. Lei Complementar $\mathbf{N}^{\circ} \mathbf{3 1}$ de 17 de Julho de 2014. Dispõe sobre o Zoneamento de Uso e Ocupação do Solo Urbano e Rural do Município de Campo Mourão e dá outras providências. Campo Mourão: Secretaria do Planejamento Interino, 2014.

QUEIROZ, Adriana Renata Sathler de; MOTTA-VEIGA, Marcelo. Análise dos impactos sociais e à saúde de grandes empreendimentos hidrelétricos: lições para uma gestão energética sustentável. Ciência e Saúde Coletiva, Rio de Janeiro, v. 17, p. 1387-1398, 2012.

RELATÓRIO AMBIENTAL COPEL. Usina Hidrelétrica Mourão I. Campo Mourão: [s.n.], 1999.

ROCHA, Jacqueline Carril Ferreira da et al. Uso e ocupação do solo na Amazônia: a influência de uma usina hidrelétrica. In: SAFETY, HEALTH AND ENVIRONMENT WORLD CONGRESS, 13., 2013. Porto. Anais [...] Porto: COPEC, 2013. p. 317-321

VON SPERLING, Eduardo. Água para saciar corpo e espirito: balneabilidade e outros usos nobres. In: CONGRESSO BRASILEIRO DE ENGENHARIA SANITÁRIA E AMBIENTAL, 22., 2003, Joinville Anais [...] Joinville: ABES, 2003.

Recebido em: 15/04/2019 Aprovado em: 14/08/2019

Universidade do Estado de Santa Catarina - UDESC Centro de Ciências Humanas e da Educação - FAED

Revista PerCursos Volume 20 - Número 43 - Ano 2019 revistapercursos@gmail.com 